Primljen / Received: 1.1.2016. Ispravljen / Corrected: 19.6.2016. Prihvaćen / Accepted: 11.8.2016. Dostupno online / Available online: 10.1.2017.

\section{Finite element analysis of RC elements in progressive collapse scenario}

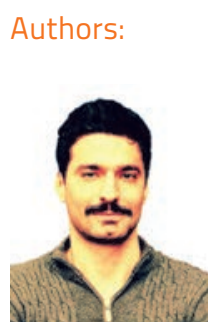

Nima Usefi, MSc. CE

Iran University of Science and Technology Department of Civil Engineering

N_yusefi@alumni.iust.ac.ir

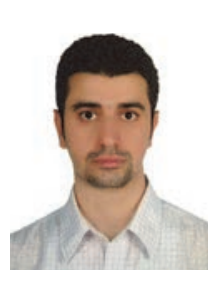

PhD student Foad Mohajeri Nav, MCE Iran University of Science and Technology Department of Civil Engineering foadmohajeri@iust.ac.ir

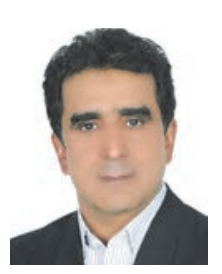

Prof. Reza Abbasnia, PhD. CE Iran University of Science and Technology Department of Civil Engineering abbasnia@iust.ac.ir

\section{Nima Usefi, Foad Mohajeri Nav, Reza Abbasnia}

\section{Finite element analysis of RC elements in progressive collapse scenario}

The applicability of the finite element method in the analysis of progressive collapse of reinforced concrete structures is evaluated using twenty RC sub-assemblages at five different scales. Qualitative comparison of results shows a good agreement between experimental results and results obtained by the finite-element method. In addition, a small error in numerical comparison of results shows the capability of the finite element model to estimate and predict behaviour of reinforced concrete elements at different scales under the progressive collapse scenario.

\section{Key words:}

progressive collapse, finite element model, reinforced concrete, sub-assemblage, central column removal

Stručni rad

Nima Usefi, Foad Mohajeri Nav, Reza Abbasnia

\section{Analiza ab elemenata u scenariju progresivnog urušavanja metodom konačnih elemenata}

U radu se vrednuje primjenjivost metode konačnih elemenata u analizi postupnog urušavanja ab konstrukcija pomoću dvadeset ab fizikalnih elemenata u pet različitih mjerila. Kvalitativna usporedba rezultata pokazala je dobru usklađenost eksperimentalnih rezultata s rezultatima proračuna metodom konačnih elemenata. Osim toga, mala pogreška u numeričkoj usporedbi rezultata pokazuje sposobnost modela konačnih elemenata da procijeni i predvidi ponašanje armiranobetonskih elemenata različitih mjerila u scenariju postupnog urušavanja.

Ključne riječi:

postupno urušavanje, model konačnih elemenata, armirani beton, ab elementi, uklanjanje srednjeg stupa

Fachbericht

Nima Usefi, Foad Mohajeri Nav, Reza Abbasnia

\section{Finite-Elemente-Analyse von Stahlbetonelementen im Scenario des progressiven Einsturzes}

In dieser Arbeit wird die Anwendbarkeit der Finite-Elemente-Methode bei der Analyse progressiver Einstürze von Stahlbetonkonstruktionen mittels 20 physikalischer Elemente in fünf verschiedenen Maßstäben bewertet. Die qualitative Gegenüberstellung der Resultate hat eine gute Übereinstimmung experimenteller Daten mit Ergebnissen der Finite-Elemente-Methode gezeigt. Außerdem weisen die geringfügigen Abweichungen beim Vergleich der numerischen Resultate die Möglichkeiten des Finite-Elemente-Modells bei der Einschätzung und Vorhersage des Verhaltens von Stahlbetonelementen verschiedener Maßstäbe im Szenario des progressiven Einsturzes auf.

Schlüsselwörter:

progressiver Einsturz, Finite-Elemente-Modell, Stahlbeton, Stahlbetonelemente, Entfernung der mittleren Stütze 


\section{Introduction}

An increase in damage caused by progressive collapse of structures has led to the expansion of research activities concentrating on prediction of structural behaviour. Since experimental tests for progressive collapse are time consuming and expensive, numerical and theoretical models have emerged as suitable alternatives for solving such problems, and have increasingly been in the focus of attention of researchers in recent years.

One of the first theoretical studies on progressive collapse of structures was conducted by Gross et al. [1]. A computer analysis program capable of tracing behaviour of framed structures through collapse was presented in this research. Casciati et al. [2] also used 2D reinforced concrete frames to study seismic reliability in a progressive collapse scenario. In a number of recent studies, simpler models were proposed instead of complicated analyses for simulation of progressive collapse. Sasani et al. [3] used detailed models to model bar fracture of reinforced concrete frame structures. Tsai et al. [4] conducted the progressive collapse analysis following the linear static analysis procedure recommended by the US General Service Administration (GSA) [5]. Ahmadi et al. [6] typically represented a 2D and 3D model for their Experimental and Numerical Evaluation of Progressive Collapse Behavior in Scaled RC Beam-Column Subassemblage.

Non-linear analyses of progressive collapse, as used in DoD and GSA $[5,7]$ instructions, and also in the studies by Grierson et al., and Mohajeri et al. $[8,9]$, were made based on the use of the Dynamic Amplification Factor (DAF) in order to consider dynamic effects during the analytic process. In the studies of Izzuddin et al., Powell, Vlassis, Marjanishvili et al., Alashker et al. [10-14], a non-linear static analysis, with some considerations, was used to examine relevant dynamic effects. The analysis of progressive collapse was made in the study of Ellingwood et al. [15] by means of energy balance of internal and external forces.

In other studies, a threat-dependent analysis was employed, in which the initiating events are explicitly modelled. Luccioni et al. [16] used detailed models to analyse structural failure of an existing reinforced concrete building caused by a blast load. Talaat et al. [17] developed an approach using reduced models to simulate structural collapse of RC structures under earthquake action. Faridmehr et al. [18] considered preNorthridge connections to evaluate extreme load performance of steel sub-assemblage in progressive collapse.

Table 1. Specimen details

\begin{tabular}{|c|c|c|c|c|c|c|c|c|c|}
\hline \multirow{3}{*}{ Reference } & \multirow{3}{*}{ Specim. } & \multirow{3}{*}{ Scale } & \multirow{3}{*}{$\begin{array}{l}\text { Beam span } \\
{[\mathrm{mm}]}\end{array}$} & \multirow{3}{*}{$\begin{array}{c}\text { Beam section } \\
{[\mathrm{mm}]}\end{array}$} & \multicolumn{4}{|c|}{ Longitudinal reinforcement } & \multirow{3}{*}{ Stirrup } \\
\hline & & & & & \multicolumn{2}{|c|}{ At joint } & \multicolumn{2}{|c|}{ At beam span } & \\
\hline & & & & & Top & Bottom & Top & Bottom & \\
\hline \multirow{2}{*}{ [22] } & IMF & 1 & 5385 & $500 \times 700$ & $4 Ф 25$ & $2 \Phi 29$ & $2 \Phi 25$ & $2 \Phi 29$ & $\Phi 12$ \\
\hline & SMF & 1 & 5232 & $660 \times 860$ & $7 Ф 25$ & $6 Ф 25$ & $4 Ф 25$ & $4 Ф 25$ & $\Phi 12$ \\
\hline \multirow{2}{*}{ [23] } & s1 & 0.5 & 2750 & $150 \times 250$ & $1 \Phi 13+2 \Phi 10$ & $2 \Phi 10$ & $2 \Phi 10$ & $2 \Phi 10$ & Ф6 \\
\hline & s2 & 0.5 & 2750 & $151 \times 250$ & ЗФ10 & $2 \Phi 10$ & $2 \Phi 10$ & $2 \Phi 10$ & Ф6 \\
\hline \multirow{6}{*}{ [24] } & s3 & 0.5 & 2750 & $152 \times 250$ & ЗФ13 & $2 \Phi 10$ & $2 \Phi 13$ & $2 \Phi 10+1 \Phi 13$ & Ф6 \\
\hline & s4 & 0.5 & 2750 & $153 \times 250$ & ЗФ13 & $2 \Phi 13$ & $2 \Phi 13$ & $2 \Phi 13$ & Ф6 \\
\hline & s5 & 0.5 & 2750 & $154 \times 250$ & ЗФ13 & ЗФ13 & $2 \Phi 13$ & ЗФ13 & $\Phi 6$ \\
\hline & s6 & 0.5 & 2750 & $155 \times 250$ & ЗФ16 & $2 \Phi 13$ & $2 \Phi 16$ & $2 \Phi 13$ & Ф6 \\
\hline & s7 & 0.5 & 2150 & $156 \times 250$ & ЗФ13 & $2 \Phi 13$ & $2 \Phi 13$ & $2 \Phi 13$ & Ф6 \\
\hline & s8 & 0.5 & 1550 & $157 \times 250$ & ЗФ13 & $2 \Phi 13$ & $2 \Phi 13$ & $2 \Phi 13$ & $\Phi 6$ \\
\hline \multirow{2}{*}{ [25] } & $5 G$ & 0.37 & 1562 & $150 \times 185$ & $2 \Phi 10$ & $2 \Phi 10$ & $2 \Phi 10$ & $2 \Phi 10$ & Ф6 \\
\hline & $5 S$ & 0.37 & 1562 & $150 \times 225$ & $5 Ф 10$ & $2 \Phi 10$ & $2 \Phi 10$ & ЗФ10 & $\Phi 6$ \\
\hline \multirow{6}{*}{ [26] } & A1 & 0.333 & 1225 & $150 \times 300$ & $2 \Phi 12$ & $2 \Phi 12$ & $2 \Phi 12$ & $2 \Phi 12$ & Ф8 \\
\hline & A2 & 0.333 & 1225 & $150 \times 301$ & ЗФ12 & ЗФ12 & $3 Ф 12$ & ЗФ12 & Ф8 \\
\hline & A3 & 0.333 & 1225 & $150 \times 302$ & ЗФ14 & ЗФ14 & ЗФ14 & ЗФ14 & Ф8 \\
\hline & A4 & 0.333 & 1225 & $150 \times 303$ & $2 \Phi 12$ & $1 Ф 14$ & $2 \Phi 12$ & 1Ф14 & Ф8 \\
\hline & A5 & 0.333 & 1225 & $150 \times 304$ & ЗФ12 & $2 \Phi 12$ & 3Ф12 & $2 \Phi 12$ & Ф8 \\
\hline & A6 & 0.333 & 1225 & $150 \times 305$ & ЗФ14 & $2 Ф 14$ & ЗФ14 & $2 Ф 14$ & Ф8 \\
\hline \multirow{2}{*}{ [27] } & p1 & 0.25 & 1900 & $100 \times 180$ & 4Ф10 & 4Ф10 & 4Ф10 & $4 Ф 10$ & Ф6 \\
\hline & p2 & 0.25 & 1300 & $80 \times 140$ & $4 \Phi 10$ & $4 Ф 10$ & $4 Ф 10$ & $4 Ф 10$ & $\Phi 6$ \\
\hline
\end{tabular}


Based on research of explosive loads, Kwasniewski [19] examined progressive collapse in an eight-story building using non-linear finite element simulations and GSA Analysis. Hao et al. [20] and Shi et al. [21] also considered explosive loads in their analyses, and a new method was proposed for the analysis of progressive collapse in reinforced concrete frames.

Due to high cost of experimental testing, the finite element (FE) method can be a good alternative for analysing buildings under progressive collapse; however, there is still no suitable assessment of the FE method capability for analysing progressive collapse of reinforced concrete buildings. Therefore, due to lack of a comprehensive framework, the present research elaborates capabilities of the finite element method for analysing progressive collapse of reinforced concrete frames, and specifies limitations of this method through the study of its weaknesses. Twenty previously tested RC sub-assemblages [22-27] with five different scales were used and analysed for this purpose. Each of these sub-assemblages included two beams, one central joint and two corner columns. All the analyses were conducted using ABAQUS 6.13 [28].

\section{Details of specimens}

Geometry, stirrup and bar details for twenty specimens are presented in Table 1. In addition, properties of concrete and steel materials in specimens are presented in Tables 2 and 3, respectively. Further details can be found in literature [22-27].

\section{Finite element framework}

As already mentioned, a finite element framework is described in order to analyse and estimate the behaviour of sub-assemblages under the column removal scenario. All analyses were conducted via ABAQUS 6.13 [28]. Generally, the following steps should be considered for analysing progressive collapse of a RC subassemblage based on the finite element method:

- concrete modelling

- steel reinforcement modelling

- concrete-steel interaction

- finite element specifications,

- Mesh details

- boundary conditions.

Table 2. Steel properties

\begin{tabular}{|c|c|c|c|c|c|c|c|}
\hline Reference & Specimen & Scale & Bar type & $\begin{array}{c}\text { Diameter } \\
{[\mathrm{mm}]}\end{array}$ & $\begin{array}{l}\text { Yield strength } \\
{[\mathrm{MPa}]}\end{array}$ & $\begin{array}{c}\text { Strength } \\
\text { [MPa] }\end{array}$ & $\begin{array}{c}\text { Ultimate strain } \\
{[\%]}\end{array}$ \\
\hline \multirow{3}{*}{ [22] } & \multirow{3}{*}{$\begin{array}{l}\text { IMF } \\
\text { SMF }\end{array}$} & \multirow{3}{*}{1} & $\Phi 12$ & 12 & 524 & 700 & 15 \\
\hline & & & $\Phi 25$ & 25 & 476 & 648 & 21 \\
\hline & & & $\Phi 29$ & 29 & 462 & 641 & 18 \\
\hline \multirow{4}{*}[23,24]{} & \multirow{4}{*}{$\begin{array}{c}\text { S1.S2.S3 } \\
\text { S4.S5.S6 } \\
\text { S7.S8 }\end{array}$} & \multirow{4}{*}{0.5} & $\Phi 6$ & 6 & 349 & 459 & - \\
\hline & & & $\Phi 10$ & 10 & 511 & 622 & 11 \\
\hline & & & $\Phi 13$ & 13 & 494 & 593 & 10.92 \\
\hline & & & Ф 16 & 16 & 513 & 612 & 13.43 \\
\hline \multirow{2}{*}{ [25] } & \multirow{2}{*}{$\begin{array}{l}5 G \\
5 S\end{array}$} & \multirow{2}{*}{0.37} & $\Phi 6$ & 6 & 363 & 423 & 17 \\
\hline & & & $\Phi 10$ & 9.53 & 493 & 611 & 11 \\
\hline \multirow{3}{*}{ [26] } & \multirow{3}{*}{$\begin{array}{l}\text { A1.A2.A3 } \\
\text { A4.A5.A6 }\end{array}$} & \multirow{3}{*}{0.33} & $\Phi 8$ & 8 & 290 & 455 & 33 \\
\hline & & & $\Phi 12$ & 12 & 350 & 540 & 26 \\
\hline & & & Ф 14 & 14 & 340 & 535 & 27 \\
\hline \multirow{3}{*}{ [27] } & \multirow{3}{*}{$\begin{array}{l}\text { P1 } \\
\text { P2 }\end{array}$} & \multirow{3}{*}{0.25} & $\Phi 6$ & 6 & 355 & 465 & 17.5 \\
\hline & & & $\Phi 10$ & 10 & 437 & 568 & 13.1 \\
\hline & & & Ф 13 & 13 & 535 & 611 & 11.6 \\
\hline
\end{tabular}

Table 3. Concrete properties

\begin{tabular}{|c|c|c|c|c|c|c|c|c|c|c|c|c|c|c|c|c|c|c|c|c|}
\hline Reference & \multicolumn{2}{|c|}{ [22] } & \multicolumn{8}{|c|}{$[23,24]$} & \multicolumn{2}{|c|}{ [25] } & \multicolumn{6}{|c|}{ [26] } & \multicolumn{2}{|c|}{ [27] } \\
\hline Scale & \multicolumn{2}{|c|}{1} & \multicolumn{8}{|c|}{0.5} & \multicolumn{2}{|c|}{0.37} & \multicolumn{6}{|c|}{0.333} & \multicolumn{2}{|c|}{0.25} \\
\hline Specimen & IMF & SMF & S1 & $\mathrm{S2}$ & S3 & S4 & S5 & 56 & S7 & S8 & $5 G$ & $5 S$ & A1 & A2 & A3 & A4 & A5 & A6 & P1 & P2 \\
\hline $\begin{array}{l}\text { Compressive } \\
\text { strength } \\
{[\mathrm{MPa}]}\end{array}$ & 31 & 36 & 31.2 & 31.2 & 38.2 & 38.2 & 38.2 & 38.2 & 38.2 & 38.2 & 17 & 17 & 32.3 & 35.3 & 39 & 29 & 33.1 & 35.8 & 19.9 & 20.8 \\
\hline
\end{tabular}




\subsection{Concrete modelling}

As concrete behaves differently in compression and tension, its accurate modelling is always a challenge. A concrete damaged plasticity model (CDPM), previously introduced by Lubniner et al. [29], and further developed by Lee [30], is used in this study. The CDPM assumes two main failure mechanisms in concrete, i.e. the tensile cracking and the compressive crushing. The uniaxial tensile and compressive behaviour are characterized by damaged plasticity. A post failure stress-strain relationship subjected to tension is used in order to simulate the complete tensile behaviour of reinforced concrete in ABAQUS. The tensile stress-strain relationship for concrete is shown in Figure 1.a. To develop this model, the Young's modulus $\left(E_{0}\right)$, tensile stress $\left(\sigma_{t}\right)$, cracking strain value $\left(\varepsilon_{t}^{\sim c k}\right)$, and damage parameter value $\left(d_{t}\right)$, are defined for concrete. To express the compressive stress-strain relation of concrete, the compressive stress $\left(\sigma_{c}\right)$, inelastic strain $\left(\varepsilon_{c}^{\sim \text { in }}\right)$ corresponding to stress value, and damage property $\left(d_{c}\right)$ with inelastic strain, are also determined. A typical compressive stress-strain relationship
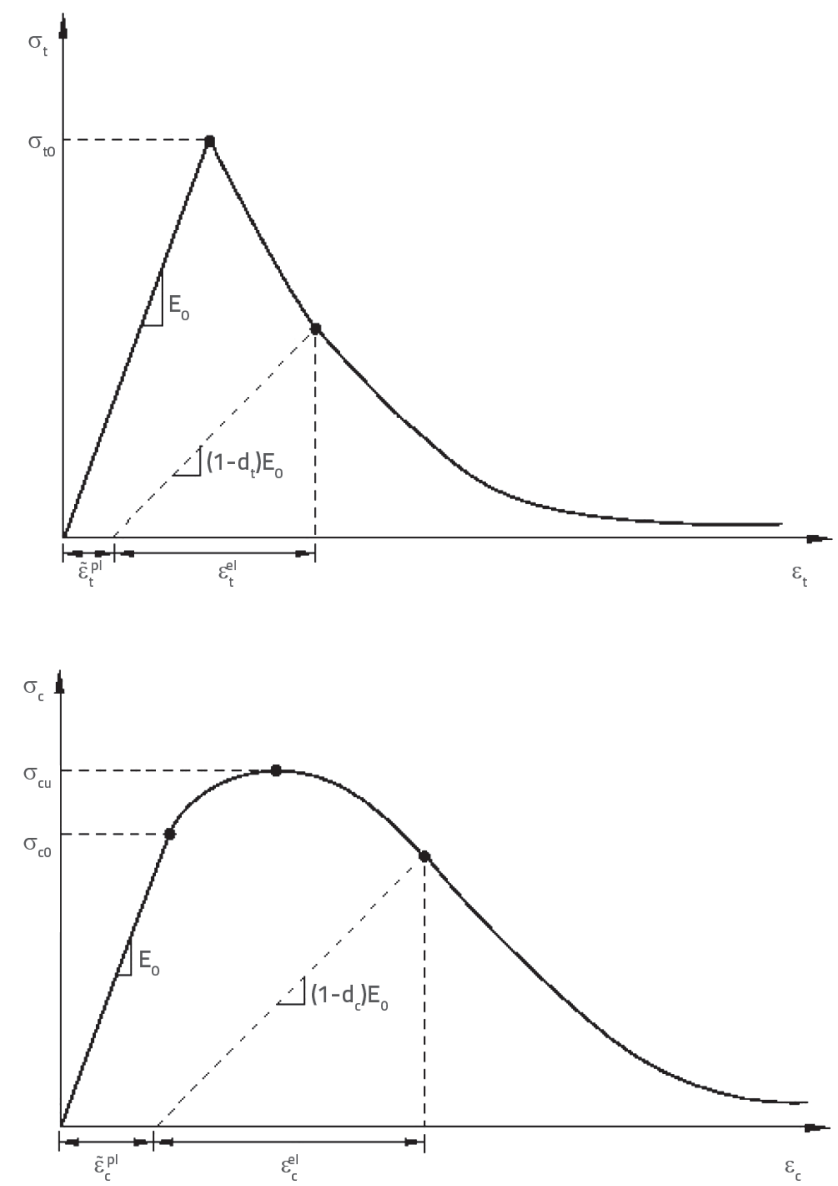

Figure 1. Stress-Strain Relationship: Tensile (top); Compressive (bottom) with damage properties and terms is shown in Figure 1.b. In addition, the CDPM uses the Willam-Warnke failure criterion for failure effects, and Hillerborg fracture energy for crack propagation. Additional specifications can be found in literature [28]. For CDPM the dilation angle, eccentricity, $\mathrm{f}_{\mathrm{bo}}$ ' $\mathrm{f}_{\mathrm{c} 0^{\prime}} \mathrm{k}$ and viscosity were taken to be $40,0.1,1.16,0.666$ and 0.001 , respectively.

\subsection{Steel reinforcement modelling}

Steel reinforcement is used in form of bars in reinforced concrete structures, and so only uniaxial behaviour has to be modelled here. The elastic-plastic behaviour is required for failure simulation. In this model, steel behaviour is completely elastic before the yield stress and, after that, it is plastic and nonlinear up to failure. The Von-Mises yield criterion is used to define the plastic region [28].

\subsection{Concrete-steel interaction}

The embedded element model is used in this study for modelling the concrete to steel interaction. This method is useful for static and dynamic analysis, and is applicable in both linear and non-linear analyses of progressive collapse. This interaction is a complete interaction without slippage. It is based on the following assumptions [28]:

1. reinforcement does not have an independent degree of freedom

2. degrees of freedom for reinforcement elements are determined based on movements of concrete elements.

If a steel element node is placed among concrete elements, its degrees of freedom are removed and the node changes into an embedded element. Hence, degrees of freedom in the embedded node are calculated using the degrees of freedom in the adjacent concrete element nodes [28].

\subsection{Finite element specifications}

A C3D8R element, defined as a 3D cubic element with eight nodes, is used for concrete modelling [28]. There are two methods for finite element modelling of steel bars. In the first method, bars are modelled in individual elements while in the second method, instead of using an independent element, the effects of bars are considered via stiffness of concrete elements. Studies show that the first method leads to better results in the finite element analysis of reinforced concrete sub-assemblages. Hence, a T3D2 element, which is a 3D truss element with two nodes, is used for bar modelling [28]. Since axial force has the basic role in steel bars, this linear model is used instead of a multi-nodal element. This would reduce the time and also the amount of computational efforts. 


\subsection{Mesh details}

In general, inconsistent results will not occur by a small variation in mesh size. Moreover, the need for selecting a very refined mesh depends on the objectives of the analysis, geometrical dimensions of specimens, and computational budget. On the other hand, studies on mesh sensitivity in static analysis indicate that accurate results for concrete pressure and tension are obtained with mesh size between 20 and $76 \mathrm{~mm}[22,31]$. The level of refinement in the above described solid element mesh is considered adequate to obtain a reasonable global response of the test specimens. Additional mesh refinement would be required only to directly capture concrete crack propagation; however, this is beyond the scope of this paper. In each specimen, the mesh size is selected using two strategies. First, finite element studies conducted on reinforced concrete specimens specify a suitable range for mesh size $[22,32,33]$. Second, the mesh size is selected via testing and selecting several mesh sizes and comparing the results with experimental results. Hence, the mesh size for SOLID elements in specimens S1 to S8, IMF and SMF was selected with two values, 35 and $55 \mathrm{~mm}$. The mesh size of 28 and $45 \mathrm{~mm}$ was selected for specimens $A 1$ to $A 6$. The mesh size was 25 and 50 mm for specimens $P 1$ and $P 2$, and 30 and $50 \mathrm{~mm}$ for specimens $5 \mathrm{G}$ and $5 \mathrm{~S}$. Refined mesh sizes (20, 28 and $35 \mathrm{~mm}$ ) in SOLID elements were utilized in critical regions, within the joint and along the beam for a distance of one beam depth from the face of the beam-column joints. Coarser meshes were used in all other regions. The mesh size of truss elements representing beam-longitudinal bars was $100 \mathrm{~mm}$, while for other truss elements representing stirrup it ranged from 80 $\mathrm{mm}$ to $125 \mathrm{~mm}$. HEX element shape and STRUCTURE technique were used in meshing concrete. The mesh size of specimens is presented in Table 4.

\subsection{Boundary condition and loading}

Finite element models are largely dependent on the speed of loading, i.e. the results are far from reality in static analysis, when the speed of loading is not in the static range. Hence, the static loading was applied on the central joint via a control displacement process in the finite element model. The load speed in specimens IMF and SMF is $0.416 \mathrm{~mm} / \mathrm{s}$.
In specimens $\mathrm{S} 1$ to $\mathrm{S} 8$ it is $0.1 \mathrm{~mm} / \mathrm{s}$, while it amounts to $0.083 \mathrm{~mm} / \mathrm{s}$ in specimens $A 1$ to $A 6$. Since the load speed for specimens 5G, 5S, P1 and P2 is not mentioned in the report of the experiment, the speed of $0.1 \mathrm{~mm} / \mathrm{s}$ was used to simulate static loading conditions for these specimens. Furthermore, boundary conditions for each of the specimens have been modelled taking into account their experimental conditions. Bars with real diameter, hook and splice were used in FE model to enable better simulation of experimental conditions.

\section{Results}

After control-displacement analysis, the FE results were compared with experimental results. Different scales were examined to find the effects of scale on the results. The forcedisplacement curve of central connection, and development of stress contours in concrete and rebars, are indicated at any scale. Capabilities of the finite element model are presented below via error percentage in FE results. 

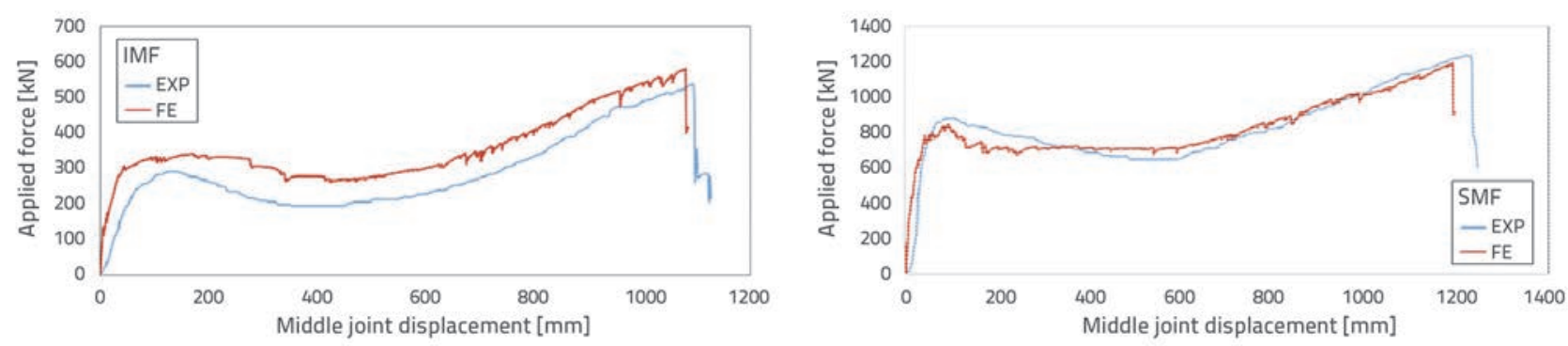

Figure 2. Vertical load versus vertical displacement of central column for full-scale IMF and SMF specimens

\subsection{Results for IMF and SMF specimens (full scale)}

Vertical load versus vertical deflection of central connection is presented in Figure 2 for IMF and SMF specimens at full scale $(1 / 1)$. In case of SMF specimen the behaviour of curve is in good agreement with experimental results, where arch and catenary actions are displayed. On the other hand, the curve pattern in case of IMF specimen is similar to experimental results; however, the amount of force in FE results is greater compared to experimental results. The rotation in central connection during experimental loading caused a frame capacity reduction, and so the FE result was higher compared to experimental result. Failure criteria for IMF and SMF specimens are the fracture of bottom rebars at central connection. Hence, a sudden decline of force at the end of curves, shown in Figure 2, is due to rebar failure at central connection, where specimens collapsed.
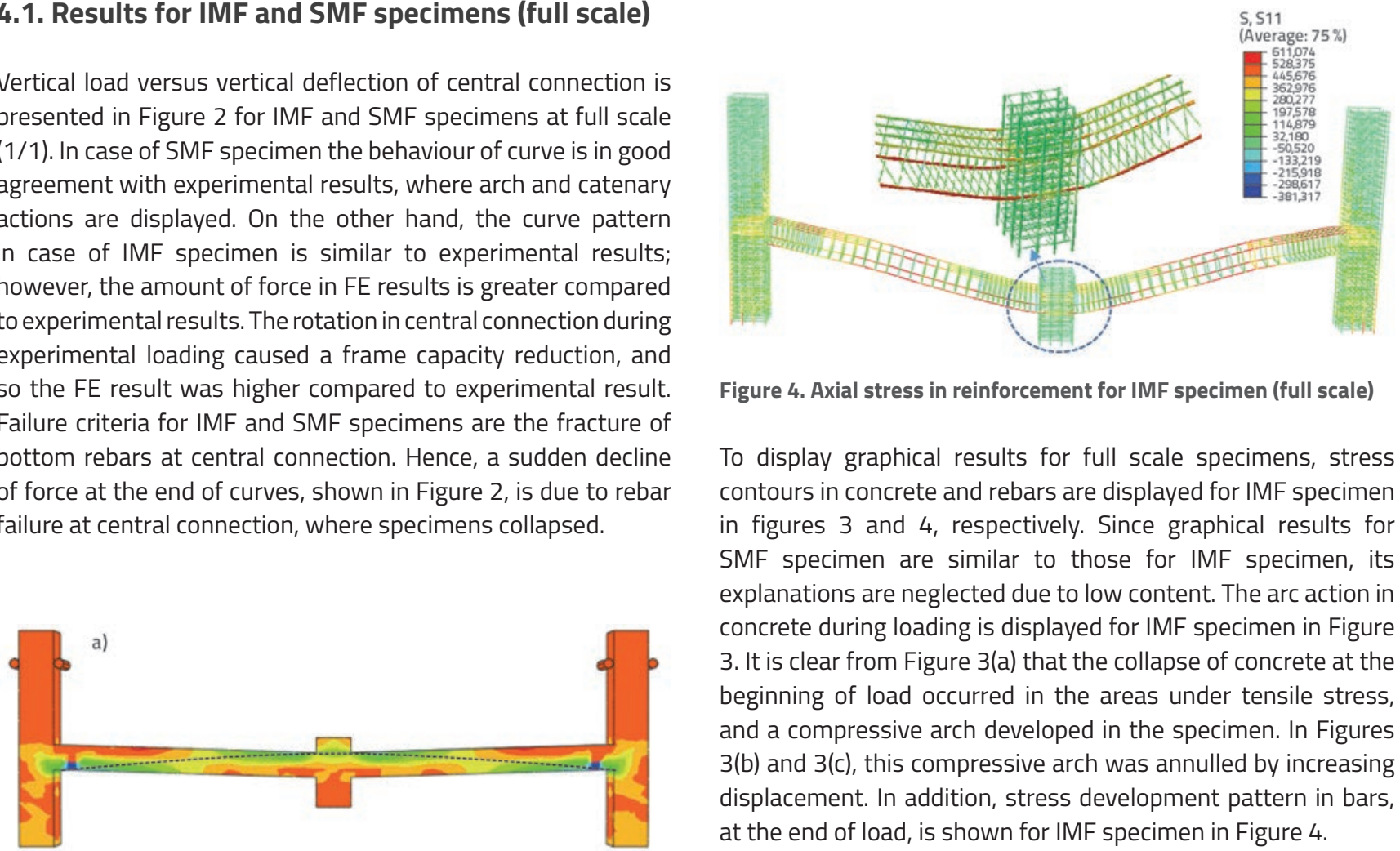

Figure 4. Axial stress in reinforcement for IMF specimen (full scale)

To display graphical results for full scale specimens, stress contours in concrete and rebars are displayed for IMF specimen in figures 3 and 4, respectively. Since graphical results for SMF specimen are similar to those for IMF specimen, its explanations are neglected due to low content. The arc action in concrete during loading is displayed for IMF specimen in Figure 3. It is clear from Figure 3(a) that the collapse of concrete at the beginning of load occurred in the areas under tensile stress, and a compressive arch developed in the specimen. In Figures $3(b)$ and $3(c)$, this compressive arch was annulled by increasing displacement. In addition, stress development pattern in bars, at the end of load, is shown for IMF specimen in Figure 4.

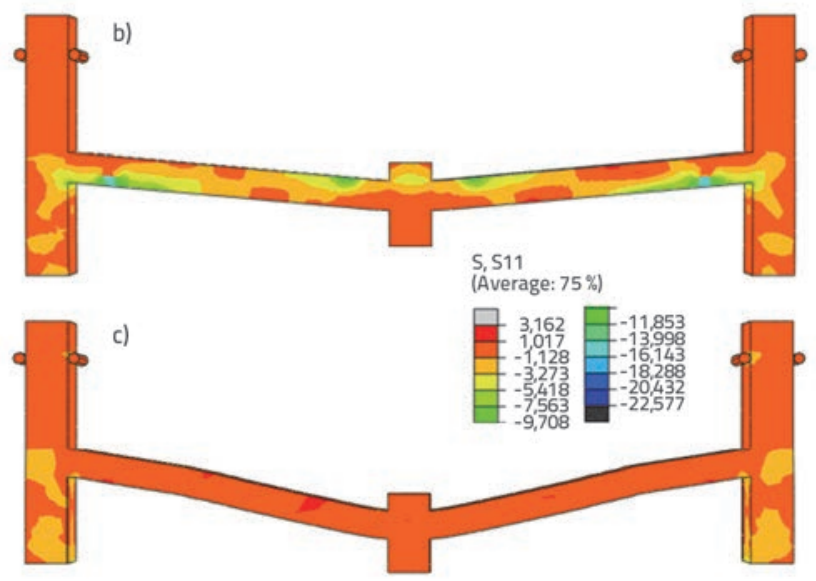

\subsection{Results for $1 / 2$-scaled specimens $\mathrm{S} 1$ to $\mathrm{S} 8$}

Vertical load versus vertical deflection of central connection is presented in Figure 5 for specimens S1 to S8 at the scale of 1/2. Rebar failure at the beam to column connection in the corner is the failure and collapse criterion for these specimens. The first sudden drop in the force-displacement curve of central connection is due to rebar failure at central connection. Under increase of displacement at central connection, the bars at corner connection were fractured and the specimens collapsed. Qualitative comparison of FE results with experimental results shows a high level of similarity in the force-displacement curve of central connection. However, there is a major difference between the FE and experimental results with regard to the time of bar fracture. The rebar fracture depends on the speed of loading, mesh size, and type of analysis. Therefore, a substantial difference occurs in rebar failure with a partial change in each 

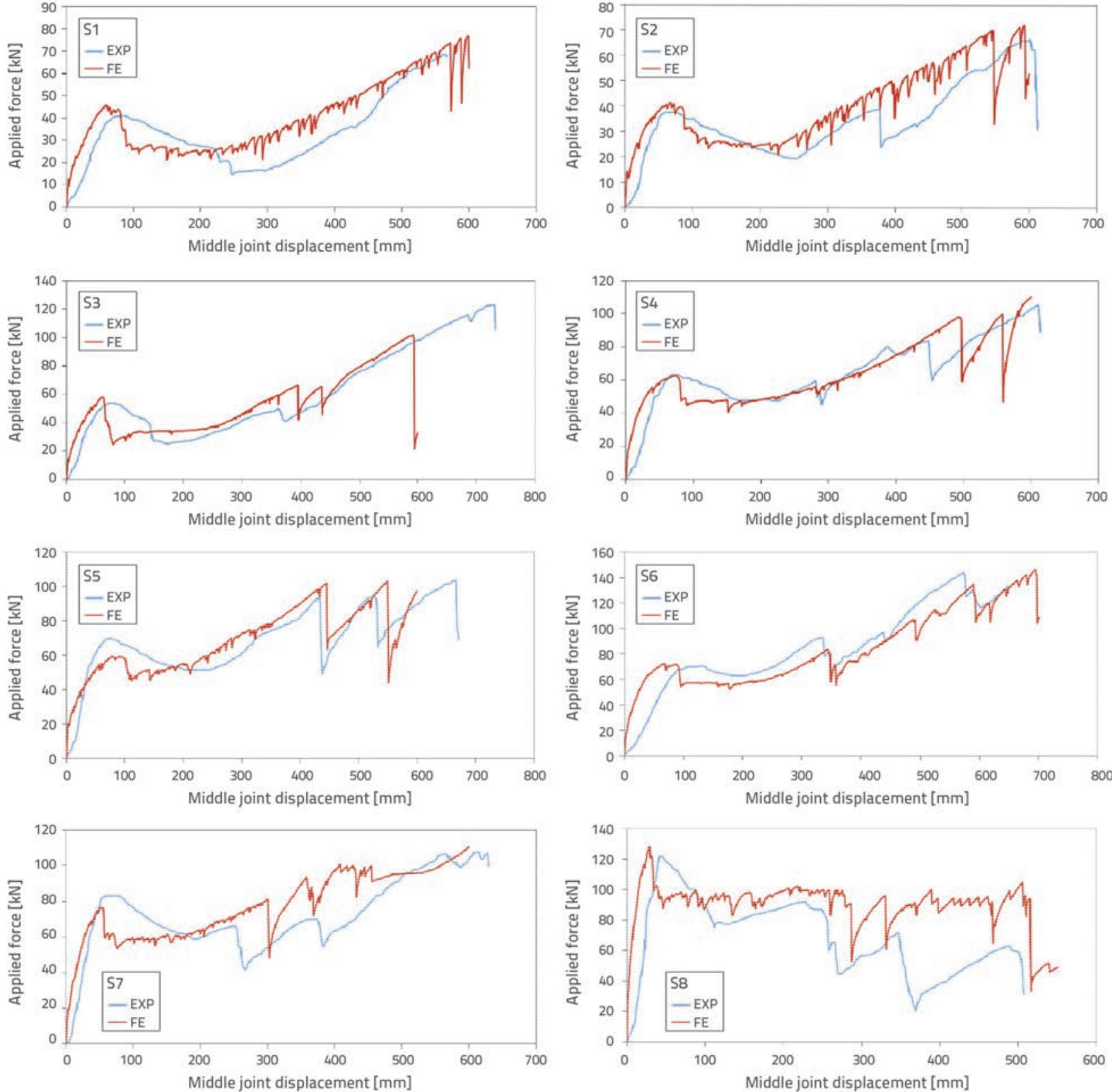

Figure 5. Vertical load versus vertical displacement of central column for $1 / 2$-scaled specimens S1 to S8

of the aforementioned parameters. Furthermore, since the interaction between concrete and rebar is a full interaction without slippage, the fracture time of rebar in FE model can differ from real tests. On the other hand, experimental errors and inhomogeneous concrete subjected to testing, and rotation of central connection due to lack of boundary conditions that would avoid rotation of central connection, are mentioned as the factors that cause change in the failure of bars. Among eight $1 / 2$-scaled specimens, shear failure occurred in specimen S8, and this type of failure is also depicted in the FE result. As shown in Figure 5, specimen $\mathrm{S} 8$ is subjected to constant failure by increasing central displacement. Due to the similarity, the results of compressive arch action for $1 / 2$-scaled specimens are shown by the results of specimen $\mathrm{S} 1$ in Figure 6.
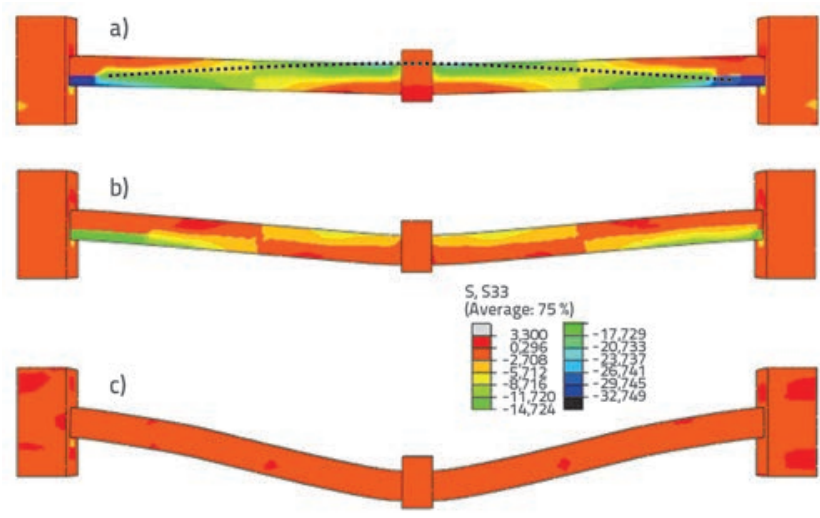

Figure 6. Compressive arch action in specimen S1: a) start of arc action; b) reduction of arc action with load increase; c) end of arc action 
Development of compressive arch action, gradual reduction of compressive arch action, and the end of compressive arch action, are presented in Figure 6. Moreover, the axial stress in rebar, and the failure of rebar in central connection, are depicted for specimen $\mathrm{S} 1$ in Figure 7.

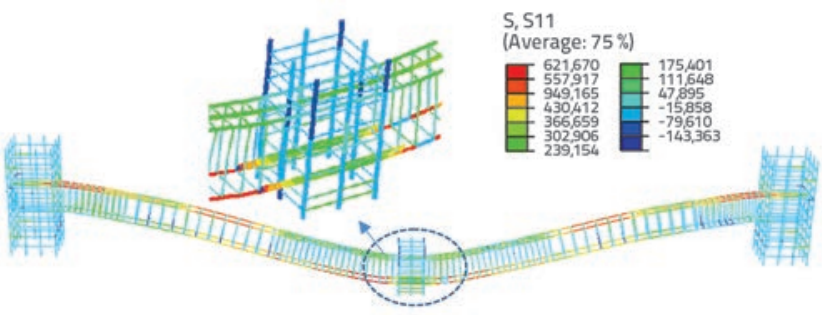

Figure 7. Axial stress in reinforcement for $1 / 2$-scaled specimen $\mathbf{S 1}$

\subsection{Results for $3 / 8$-scaled specimens $5 \mathrm{G}$ and $5 \mathrm{~S}$}

Vertical load versus vertical deflection at central connection is shown in Figure 8 for 3/8-scaled specimens $5 G$ and 55 . The comparison of $\mathrm{FE}$ results with experimental results in compressive arc region reveals considerable error in displacement values, despite similarity in the amount of force applied. In addition, the slope of the curve at the beginning of analysis is less steep in experimental results, compared to the slope in FE results. The slope at the beginning of the load displacement curve depends on elastic behaviour of concrete and rebar, elastic modulus, mesh size, load rate, and maximum concrete strength. The difference arises from the speed of loading, which is not mentioned in experiment report, and from non-homogeneity of concrete strength, as observed for experimental specimens. Furthermore, catenary action did not occur for specimen $5 \mathrm{~S}$ during the experiment. Due to low strength of concrete in experimental specimens, joints did not have the ability to restrain the rebars. Hence, the rebars fractured after crushing of concrete in the joint, which resulted in the collapse of specimens. This did not occur in finite element analysis due to complete interaction between concrete and rebar for specimen 5S, mentioned as one of limitations in the finite element model. The compressive arc action in concrete is shown in Figure 9 for specimen 5G. Graphical results for specimen 5S are not shown since the stress development pattern in specimen $5 \mathrm{~S}$ is similar to that of specimen $5 \mathrm{G}$. Collapse occurred in this compressive arch by increasing displacement in central connection. Furthermore, this compressive arch was annulled

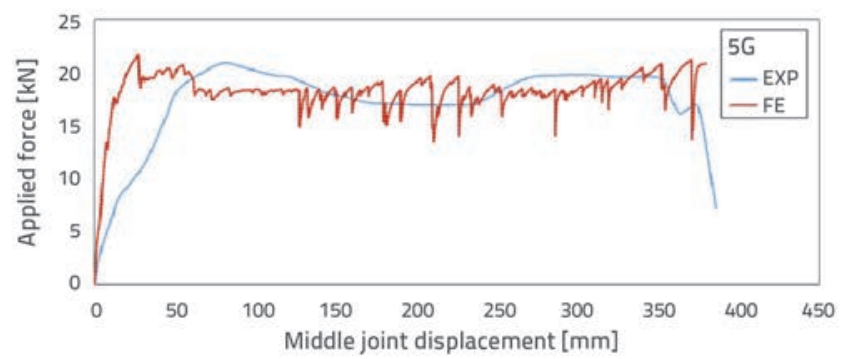

after a while, and the entire specimen was subjected to tension. The axial tension in rebars is shown for specimen $5 \mathrm{G}$ in Figure 10.

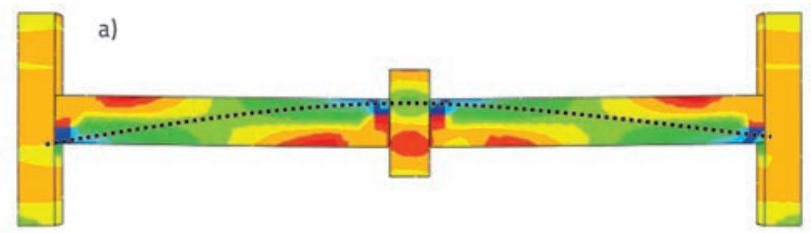

b)

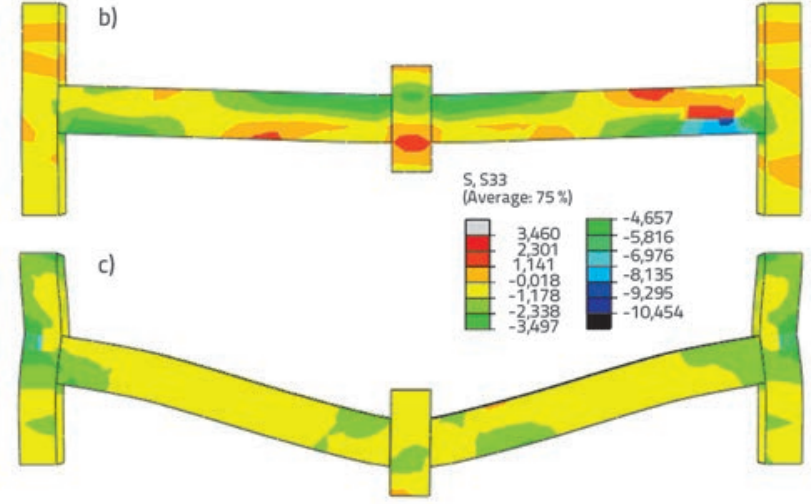

Figure 9. Compressive arch action at specimen 5G: a) start of arc action; b) reduction of arc action with load increase; c) end of arc action

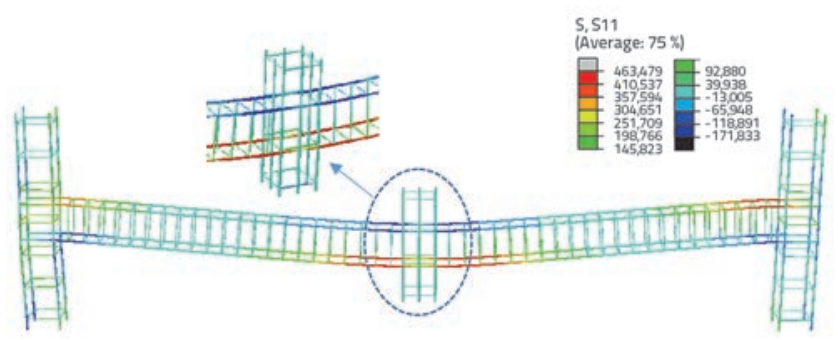

Figure 10. Axial stress in reinforcement for $3 / 8$-scaled specimen 5 G

\subsection{Results for $1 / 3$-scaled specimens $A 1$ to $A 6$}

Vertical load versus vertical deflection of central connection is presented in Figure 11 for $1 / 3$ scaled specimens $A 1$ to A6. However, experimental testing of these specimens was conducted in the range of compressive arch action only, the finite element analysis was done until rebar fracture in corner joint for achieving the catenary action. From qualitative perspective, experimental

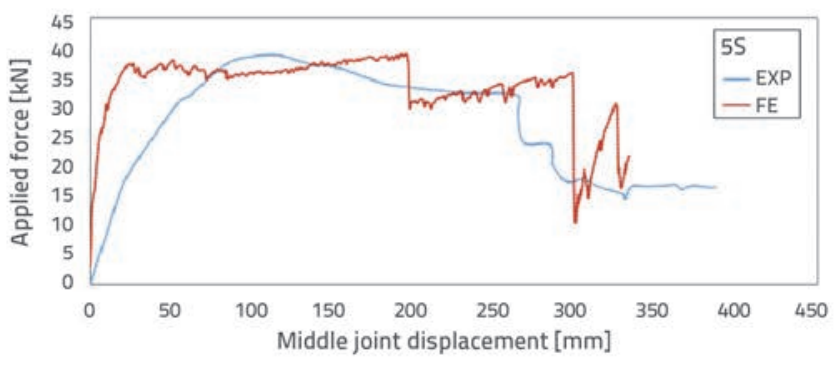

Figure 8. Vertical load versus vertical displacement of central column for 3/8-scaled specimens 5G and 5S 

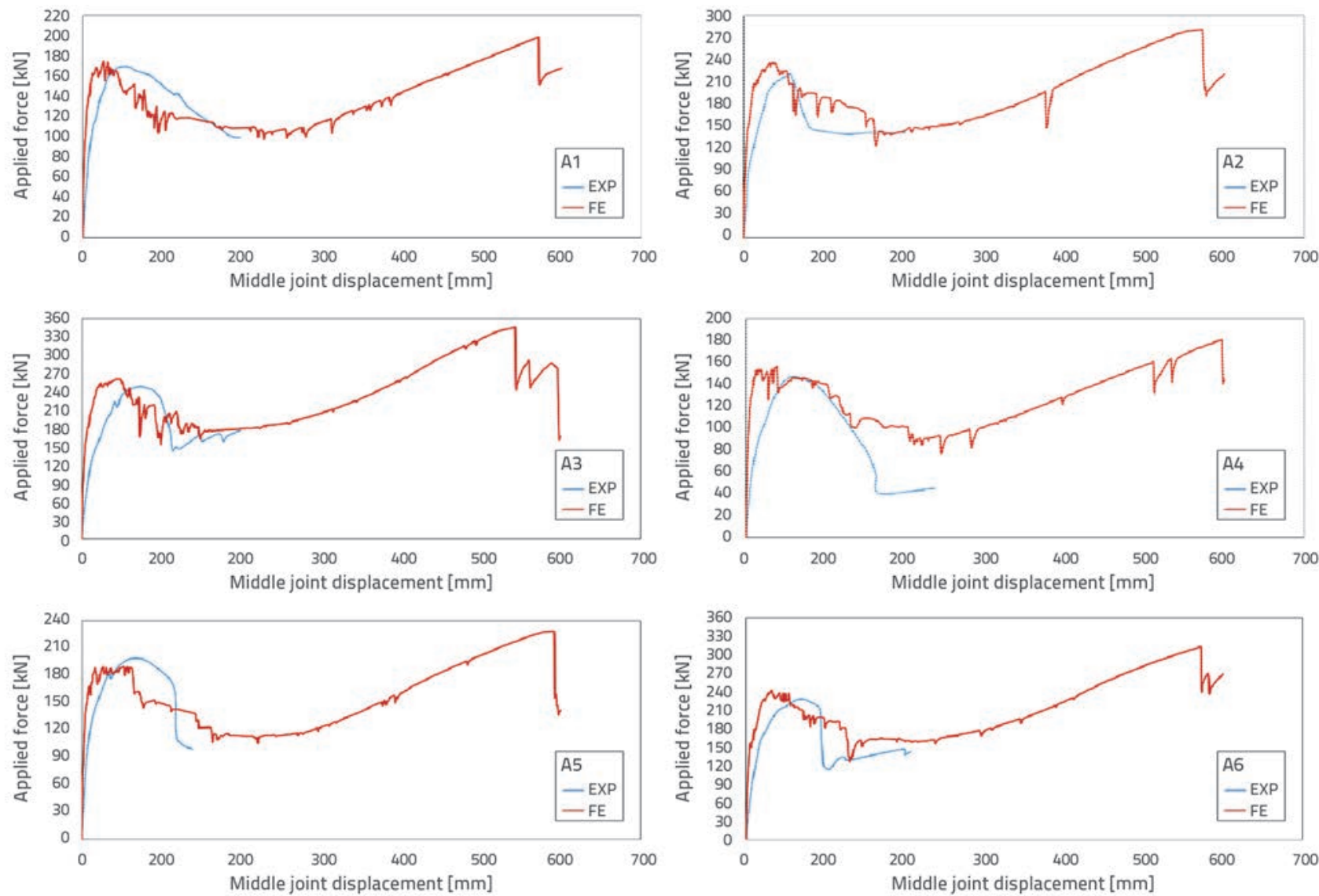

Figure 11. Vertical load versus vertical displacement of central column for $1 / 3$-scaled specimens A1 to A6

and finite element results are in good agreement in the range of compressive arch action. In the experimental test, bar fracture occurred at central connection only, which is due to short time of analysis. However, in the finite element analysis, the first and second bar ruptures occurred at the central and corner connections,
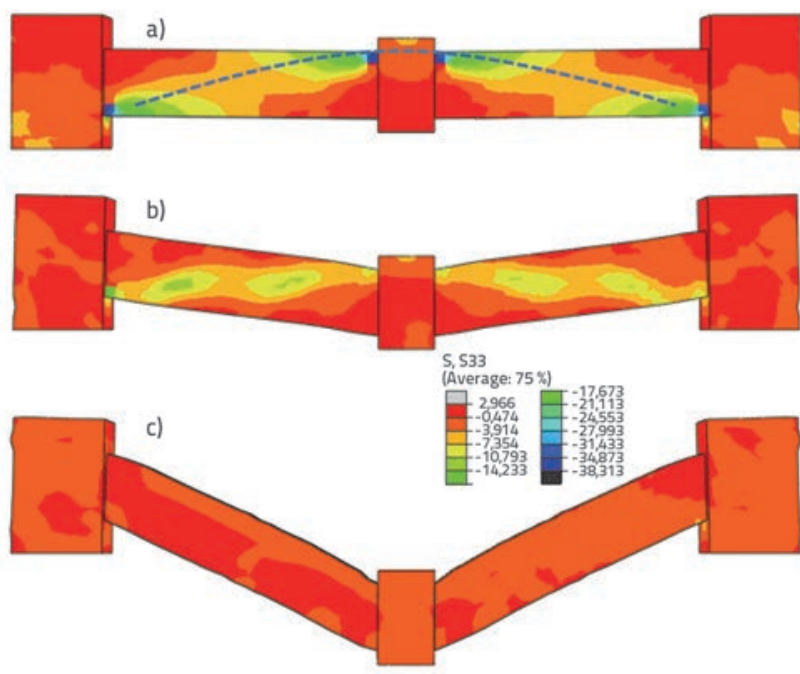

Figure 12. Compressive arch action at specimen A1: a) start of arc action; b) reduction of arc action with load increase; c) end of arc action respectively. The formation of compressive arch action, its gradual reduction, and collapse of compressive arc, is shown in Figure 12 for specimen A1. The compressive arch action can be obtained despite small span of these specimens. Furthermore, since the height of beam in these specimens is greater than the height of beam in specimens at other scales, the compressive arch region is also greater. The axial tension of bars in specimen $A 1$ in the middle of the analysis is shown in Figure 13.

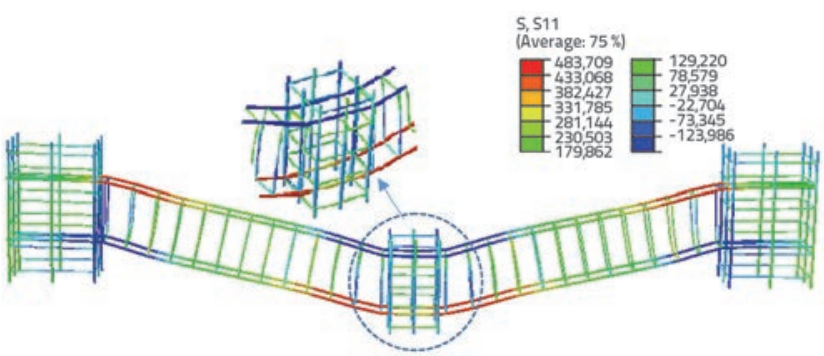

Figure 13. Axial stress in reinforcement for $1 / 3$-scaled specimen A1

\subsection{Results for $1 /$-scaled specimens $P 1$ and $P 2$}

Results of vertical load versus vertical deflection at central connection for 1/4-scaled specimens $\mathrm{P} 1$ and $\mathrm{P} 2$ are shown in Figure 14. General behaviour of curves at experimental state has an acceptable similarity with the behaviour of finite element 

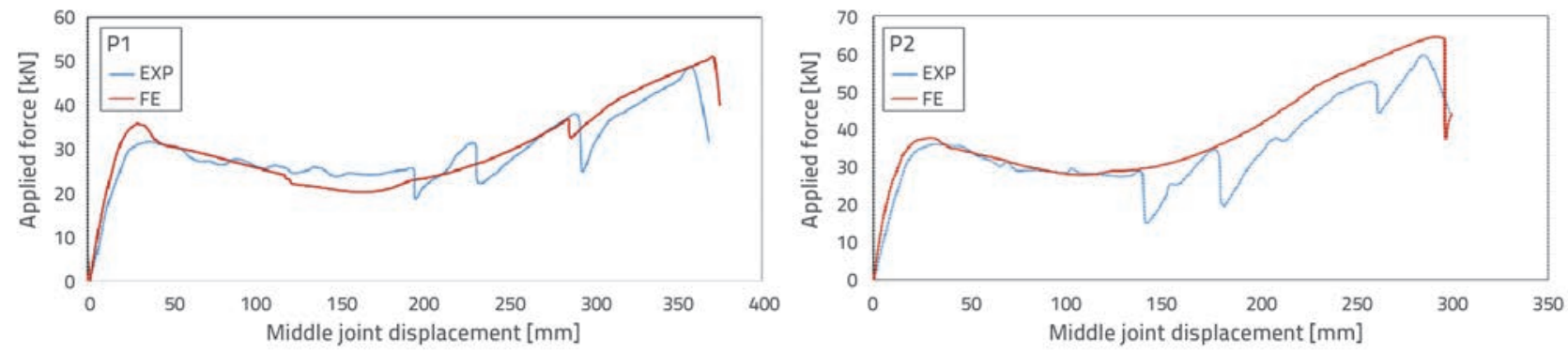

Figure 14. Vertical load versus vertical displacement at central column for $1 / 4$-scaled specimens P1 and P2

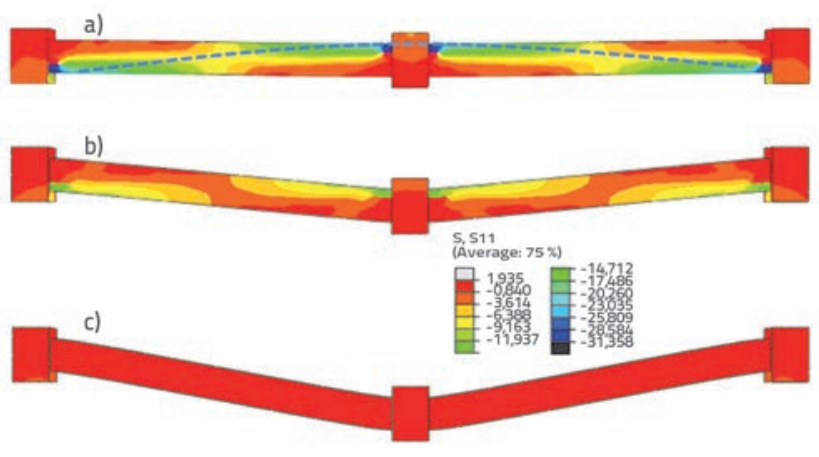

Figure 15. Compressive arch action in specimen P1: a) start of arc action; b) reduction of arc action with load increase; $c$ ) end of arc action

curves. However, rebar failure during analysis did not occur for finite element results. There is a good agreement between the compressive arch capacity, maximum catenary capacity, and transition stage for FE and experimental results. Loading speed, mentioned in experiment report that is $0.1 \mathrm{~mm} / \mathrm{s}$, can be the reason for lack of rebar failure during loading. Development of compressive arch action in 1/4-scaled specimen $\mathrm{P} 1$ is presented in Figure 15. The compressive arch disappeared in concrete as a result of load increase, when the entire specimen was subjected to tensile stresses. Furthermore, development of axial tension in the middle of analysis in the bars of specimen $\mathrm{P} 1$ is shown in Figure 16.

\section{Discussion of results}

In all sub-assemblages presented at five different scales, the load applied to central connection reduced after reaching maximum capacity and passing the compressive arch action. In the beginning and at the end of arch action, the strength capacity of specimens was increased by catenary action of rebar due to increase in displacement of central connection. The catenary action developed at that stage and then the specimens collapsed. However, the load displacement curves for FE and experimental results are in good qualitative agreement, i.e. just a few differences exist between finite elements and experimental results. In fact, due to the existing experimental errors and considering the fact that concrete is not distributed homogenously under experimental conditions,

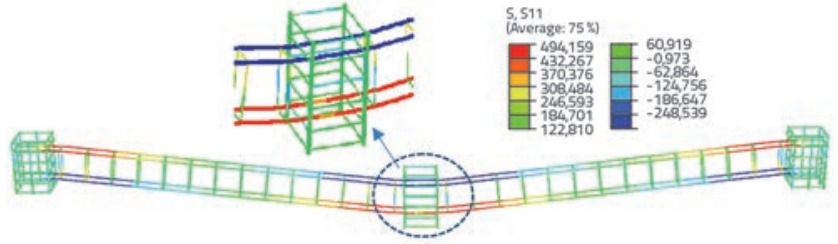

Figure 16 Axial stress in reinforcement for 1/4-scaled specimen P1

the force applied in the finite element analysis differs from experimental analysis. In addition, since concrete is modelled homogenously and the interaction between concrete and steel during loading is considered to be a complete interaction in the finite element model, the strength of reinforced concrete frames reveals several differences with regard to experimental results. The bar fracture in experimental conditions depends on the distribution of concrete in specimen, interaction between concrete and steel, load rate, and steel and concrete strength. All the aforementioned factors are necessary in the FE analysis. However, the mesh size and type of element for integration in the finite element model, are two factors that should also be considered. The type of element for integration in the finite element analysis is considered to be an effective parameter in the accuracy of results, which is controlled via the type of analysis and even the mesh parameter. The proposed finite element model has the ability to display rebar failure. The rebar fracture in central connection is shown in Figure 17 for 1/2-scaled specimen S6. Figure 17.a shows that tensile stress has reached critical point before fracture in bottom bars. In figure 17.b, the rupture occurred at two sides of connection due to increase in central displacement. Rebar failure in specimen S6 during the experiment is shown for comparison purposes in Figure 17.c. Therefore, bar failure can be simulated through accurate modelling using real rebar dimensions.

The examination of axial stress contours in all specimens at different scales shows that the compressive arch action forms in the beginning of analysis in all specimens, and this action gradually ends. Hence, the arc action can be obtained in all elements using the proposed finite element model, regardless of the scale of specimens. Due to the lack of extensive experimental data, discussion on the effects of scale on the analysis and results is complicate and requires further studies. However, comparison of the experimental and finite element data at five scales shows that no relationship exists between the 
finite element results and the scale. As mentioned previously, the accuracy of results can be achieved by proper modelling of geometry, boundary conditions, material details, mesh size, and element type. Furthermore, selection of scale must be made based on scaling principles. The finite element and experimental results are shown in Table 5. The data are organized in three parts: arch action, transient stage, and catenary action. In addition, failure mode of specimens is specified for experimental and finite element states. The FE results to experimental results relationship (FE/EXP.) is used to estimate the error percentage

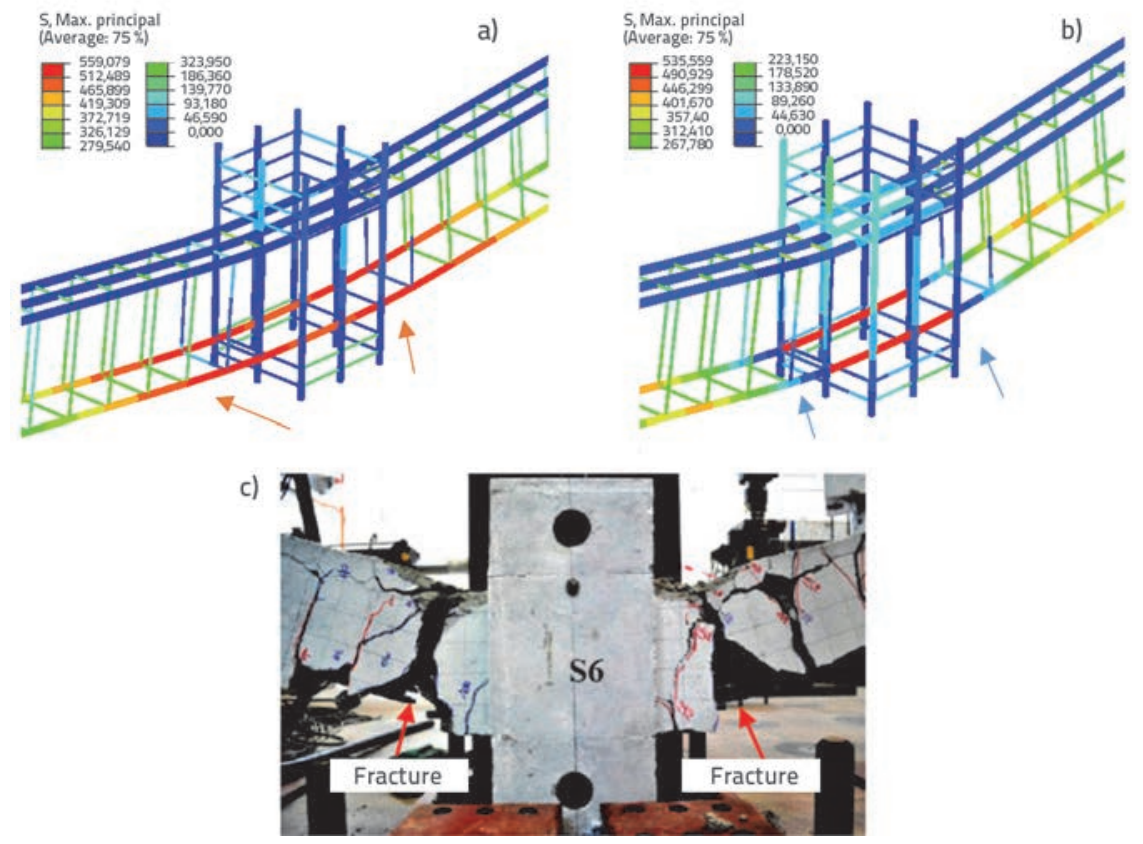

Figure 17. Rebar fracture at central joint in 1/2-scaled specimen S6: a) increase of stress in bottom reinforcement before fracture; b) rebar fracture with load increase; c) rebar fracture in experiment and similarity of data for each specimen in three stages. The mean FE/Exp values of compressive arch capacity, transient stage, and catenary capacity, amount to $1.02,1.06$, and 0.95 , respectively, indicating that the finite element model has a high capability of estimating forces and required capacities in RC sub-assemblages under progressive collapse. Furthermore, the mean FE/Exp results of related displacements for compressive arch capacity, transient stage, and catenary capacity, amount to $0.85,0.72$ and 0.91 , respectively, which shows that the finite element model exhibits greater error in predicting displacement than in the prediction of forces. In fact, at transient stage, there is a $28 \%$ error in the estimation of displacement. On the other hand, as the transient stage is not highly significant in progressive collapse, this error can be neglected due to high capability of the model.

The error percentage in the compressive arch capacity between experimental and finite element results is shown in Figure 18. The maximum error amounts to $17 \%$, which has been registered in specimen S5. In addition, the mean error for estimating compressive arch capacity of twenty specimens amounts to $6 \%$. There is no certain pattern between the error and increase in scale. Therefore, as mentioned, the results depend on the modelling details, rather than on the scale. Figure 19 shows the error percentage in the ultimate capacity of catenary action between experimental and finite element results for the studied specimens. Due to the lack of catenary

Table 5. Finite element (FE) results compared to experimental (Exp.) responses

\begin{tabular}{|c|c|c|c|c|c|c|c|c|c|c|}
\hline \multirow{2}{*}{ Reference } & \multirow{2}{*}{ Scale } & \multirow{2}{*}{ Specimen } & \multirow{2}{*}{ Results } & \multicolumn{2}{|c|}{$\begin{array}{l}\text { Compressive } \\
\text { arc action }\end{array}$} & \multicolumn{2}{|c|}{ Transient stage } & \multicolumn{2}{|c|}{ Catenary action } & \multirow{2}{*}{ Failure mode } \\
\hline & & & & $\mathbf{Y}[\mathrm{mm}]$ & $\mathbf{P}[\mathrm{kN}]$ & $\mathbf{Y}[\mathrm{mm}]$ & $\mathbf{P}[\mathrm{kN}]$ & $\mathbf{Y}[\mathrm{mm}]$ & $\mathbf{P}[\mathrm{kN}]$ & \\
\hline \multirow{6}{*}{ [22] } & \multirow{6}{*}{$1 / 1$} & \multirow{3}{*}{ IMF } & FE & 162 & 338 & 344.2 & 266.8 & 1070 & 574 & middle joint rebar fracture \\
\hline & & & EXP. & 127 & 296 & 352.8 & 196.9 & 1094 & 535 & middle joint rebar fracture \\
\hline & & & FE/EXP. & 1.28 & 1.14 & 0.98 & 1.36 & 0.98 & 1.07 & \\
\hline & & \multirow{3}{*}{ SMF } & FE & 95 & 841 & 224.5 & 676.4 & 1188 & 1188 & middle joint rebar fracture \\
\hline & & & EXP. & 107 & 882 & 510.5 & 648.4 & 1219 & 1232 & middle joint rebar fracture \\
\hline & & & FE/EXP. & 0.89 & 0.95 & 0.44 & 1.04 & 0.97 & 0.96 & \\
\hline
\end{tabular}


Table 5. Finite element (FE) results compared to experimental (Exp.) responses

\begin{tabular}{|c|c|c|c|c|c|c|c|c|c|c|}
\hline \multirow{6}{*}{ [23] } & \multirow{24}{*}{$1 / 2$} & \multirow{3}{*}{ S1 } & FE & 57 & 45 & 210.4 & 24.2 & 594 & 75 & corner joint rebar fracture \\
\hline & & & EXP. & 78 & 41.6 & 246.1 & 14.9 & 573 & 68.91 & corner joint rebar fracture \\
\hline & & & FE/EXP. & 0.73 & 1.08 & 0.85 & 1.62 & 1.04 & 1.09 & \\
\hline & & \multirow{3}{*}{$\mathrm{S} 2$} & $\mathrm{FE}$ & 71 & 40 & 188.4 & 23.5 & 592 & 72 & corner joint rebar fracture \\
\hline & & & EXP. & 73 & 38.4 & 252.3 & 19.3 & 612 & 67.6 & corner joint rebar fracture \\
\hline & & & FE/EXP. & 0.97 & 1.04 & 0.75 & 1.22 & 0.97 & 1.07 & \\
\hline \multirow{18}{*}{ [24] } & & \multirow{3}{*}{ S3 } & $\mathrm{FE}$ & 57 & 56 & 80.1 & 24.4 & 590 & 101.9 & corner joint rebar fracture \\
\hline & & & EXP. & 74.4 & 54.5 & 189.2 & 24.3 & 729.3 & 124.3 & corner joint rebar fracture \\
\hline & & & FE/EXP. & 0.77 & 1.03 & 0.42 & 1.00 & 0.81 & 0.82 & \\
\hline & & \multirow{3}{*}{$\mathrm{S} 4$} & $\mathrm{FE}$ & 77 & 62 & 152.7 & 40.4 & 599 & 109 & corner joint rebar fracture \\
\hline & & & EXP. & 81 & 63.2 & 167.1 & 47.8 & 614 & 103.7 & corner joint rebar fracture \\
\hline & & & FE/EXP. & 0.95 & 0.98 & 0.91 & 0.85 & 0.98 & 1.05 & \\
\hline & & \multirow{3}{*}{ S5 } & $\mathrm{FE}$ & 75 & 58 & 112.4 & 45.7 & 598 & 96 & corner joint rebar fracture \\
\hline & & & EXP. & 74.5 & 70.3 & 205.4 & 51.6 & 666 & 105.1 & corner joint rebar fracture \\
\hline & & & FE/EXP. & 1.01 & 0.83 & 0.55 & 0.89 & 0.90 & 0.91 & \\
\hline & & \multirow{3}{*}{ S6 } & $\mathrm{FE}$ & 90 & 71 & 178.4 & 52.7 & 692 & 142 & corner joint rebar fracture \\
\hline & & & EXP. & 114.4 & 70.3 & 181.2 & 63 & 580 & 143 & corner joint rebar fracture \\
\hline & & & FE/EXP. & 0.79 & 1.01 & 0.98 & 0.84 & 1.19 & 0.99 & \\
\hline & & \multirow{3}{*}{ S7 } & FE & 55 & 75 & 76.5 & 53.1 & 600 & 110 & ncorner joint rebar fracture \\
\hline & & & EXP. & 74.4 & 82.8 & 176.4 & 58.7 & 628 & 106 & corner joint rebar fracture \\
\hline & & & FE/EXP. & 0.74 & 0.91 & 0.43 & 0.90 & 0.96 & 1.04 & \\
\hline & & \multirow{6}{*}{$5 G$} & $\mathrm{FE}$ & 28 & 126 & 135.6 & 83.2 & 216 & 100.2 & corner joint rebar fracture \\
\hline & & & EXP. & 45.9 & 121 & 111.8 & 75.2 & 225 & 91.9 & shear failure \\
\hline & & & FE/EXP. & 0.61 & 1.04 & 1.21 & 1.11 & 0.96 & 1.09 & \\
\hline \multirow{6}{*}{ [25] } & \multirow{6}{*}{$3 / 8$} & & FE & 25 & 21 & 122.7 & 18.2 & 367 & 21.4 & corner joint rebar fracture \\
\hline & & & EXP. & 81.4 & 20.5 & 227.9 & 16.9 & 353.7 & 19.9 & corner joint rebar fracture \\
\hline & & & FE/EXP. & 0.31 & 1.02 & 0.54 & 1.08 & 1.04 & 1.08 & \\
\hline & & \multirow{3}{*}{$5 S$} & $\mathrm{FE}$ & 116.1 & 38 & 85.3 & 34 & 299.6 & 35.1 & corner joint rebar fracture \\
\hline & & & EXP. & 50 & 37 & 263.6 & 32.1 & - & - & corner joint concrete failure \\
\hline & & & FE/EXP. & 2.32 & 1.03 & 0.32 & 1.06 & - & - & \\
\hline \multirow{18}{*}[26]{} & \multirow{18}{*}{$1 / 3$} & \multirow{3}{*}{ A1 } & FE & 25 & 172 & 227 & 97.4 & 569 & 198 & corner joint rebar fracture \\
\hline & & & EXP. & 42 & 165 & - & - & - & - & middle joint rebar fracture \\
\hline & & & FE/EXP. & 0.60 & 1.04 & - & - & - & - & \\
\hline & & \multirow{3}{*}{ A2 } & $\mathrm{FE}$ & 31 & 233 & 168 & 139 & 567 & 280 & corner joint rebar fracture \\
\hline & & & EXP. & 55 & 221 & - & - & - & - & middle joint rebar fracture \\
\hline & & & FE/EXP. & 0.56 & 1.05 & - & - & - & - & \\
\hline & & \multirow{3}{*}{ A3 } & FE & 50 & 255 & 153 & 175 & 539 & 345 & corner joint rebar fracture \\
\hline & & & EXP. & 60 & 246 & - & - & - & - & middle joint rebar fracture \\
\hline & & & FE/EXP. & 0.83 & 1.04 & - & - & - & - & \\
\hline & & \multirow{3}{*}{ A4 } & FE & 35 & 150 & 211 & 85 & 595 & 180 & corner joint rebar fracture \\
\hline & & & EXP. & 64 & 146 & - & - & - & - & middle joint rebar fracture \\
\hline & & & FE/EXP. & 0.55 & 1.03 & - & - & - & - & \\
\hline & & & FE & 60 & 188 & 221 & 105 & 589 & 228 & corner joint rebar fracture \\
\hline & & A5 & EXP. & 75 & 198 & - & - & - & - & middle joint rebar fracture \\
\hline & & & FE/EXP. & 0.80 & 0.95 & - & - & - & - & \\
\hline & & & FE & 54 & 236 & 238 & 154 & 571 & 312 & corner joint rebar fracture \\
\hline & & A6 & EXP. & 65 & 215 & - & - & - & - & middle joint rebar fracture \\
\hline & & & FE/EXP. & 0.83 & 1.10 & - & - & - & - & \\
\hline
\end{tabular}


Table 5. Finite element (FE) results compared to experimental (Exp.) responses

\begin{tabular}{|c|c|c|c|c|c|c|c|c|c|c|}
\hline \multirow{6}{*}{ [27] } & \multirow{6}{*}{$1 / 4$} & \multirow{3}{*}{ P1 } & $\mathrm{FE}$ & 27.6 & 35.4 & 175.6 & 20.63 & 368.2 & 50.4 & corner joint rebar fracture \\
\hline & & & EXP. & 39 & 32 & 191.9 & 19.1 & 370 & 47 & corner joint rebar fracture \\
\hline & & & FE/EXP. & 0.71 & 1.11 & 0.92 & 1.08 & 1.00 & 1.07 & \\
\hline & & \multirow{3}{*}{$\mathrm{P} 2$} & $\mathrm{FE}$ & 29.7 & 37.4 & 111.4 & 27.1 & 293.6 & 64.7 & corner joint rebar fracture \\
\hline & & & EXP. & 36.1 & 36 & 140.1 & 29.1 & 299 & 59 & corner joint rebar fracture \\
\hline & & & FE/EXP. & 0.82 & 1.04 & 0.80 & 0.93 & 0.98 & 1.10 & \\
\hline \multicolumn{4}{|c|}{ Mean FE/ Exp. } & 0.85 & 1.02 & 0.72 & 1.06 & 0.91 & 0.95 & \\
\hline
\end{tabular}

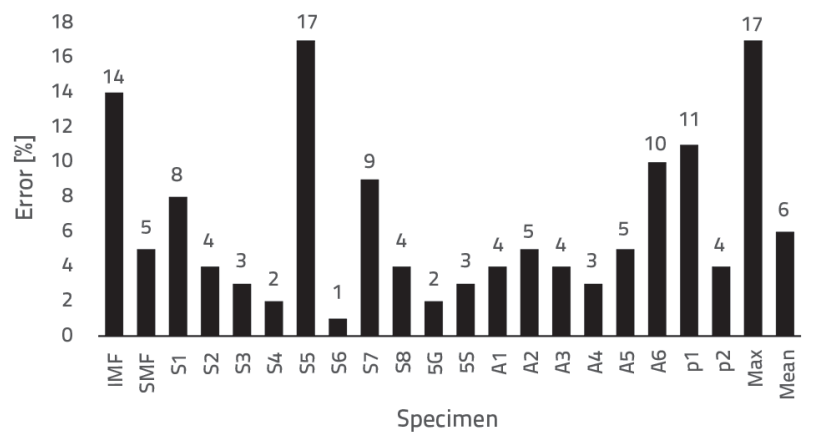

Figure 18. Error percentage between finite element and experimental results of Arc Action capacity

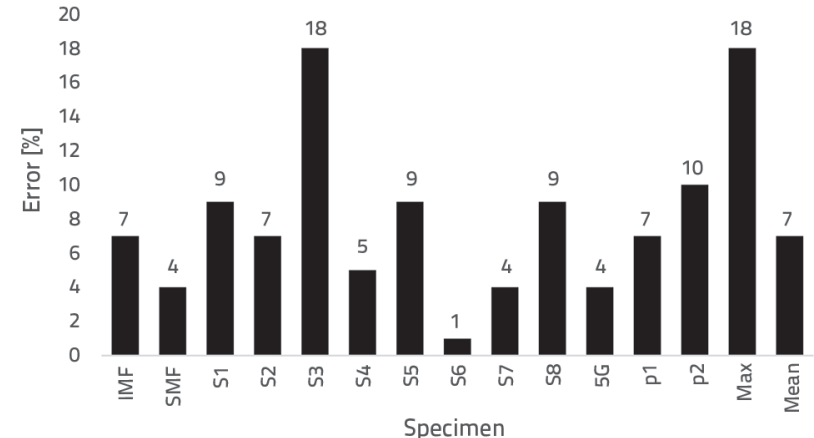

Figure 19. Error percentage between finite element and experimental results of Catenary Action capacity capacity results in the experimental test of specimens $A 1$ to $A 6$, the error is represented for the remaining specimens. Maximum error in estimating catenary capacity equals to $18 \%$, and has been registered in specimen S3. Furthermore, the mean error for the ultimate catenary action results equals to $7 \%$.

\section{Conclusion}

The authentic finite element model proposed in this study is a valuable way of predicting and analysing behaviour of real structures exposed to progressive collapse. The efficiency and ability of the finite element model to predict behaviour of reinforced concrete sub-assemblages in the column removal scenario is examined in the present research. It should be noted that dynamic parameters, including the effects of strain rate on the materials and inertia, have not been considered in this research, and that the displacement was applied gradually. The results obtained in the scope of this study are listed below.

- Qualitative comparison of the load-displacement curve for twenty specimens at five different scales showed a good agreement between experimental and finite element results. It can confirm the accuracy of the proposed model, which can be used for real reinforced concrete frames within the framework mentioned in this research.

- The proposed finite element model has the ability to estimate progressive collapse of specimens at different scales. There is no general relationship between the scale size and finite element results, which was established with variable error between different scales.

- However, the proposed model has the ability to consider rupture of bars, slippage was not considered due to full interaction between concrete and rebars. This weakness of the proposed model caused unreality and small errors in the results.

- The mean FE/Exp. in specimens showed that the proposed finite element model can estimate loading capacity better than displacement. In fact, the mean FE/Exp. for load capacity at the compressive arch action, transient stage and catenary action amounted to $1.02,1.06$, and 0.95 , respectively. On the other hand, the mean FE/Exp. for related displacements amounted to $0.85,0.72$ and 0.91 for the compressive arch action, transient stage, and catenary action, respectively. Since the estimation of load capacity in progressive collapse is more important than displacement, the $28 \%$ displacement error in transient action can be neglected.

- Graphical results for specimens indicate that the proposed finite element model can show the compressive arch behaviour of concrete at any scale. Hence, the formation and the end of compressive arc action are irrespective of scale effects.

Considering high cost of experimental studies, experimental errors, and long process of testing, the finite element model proposed in this study can be regarded as an optimal solution for estimating behaviour of reinforced concrete frames subjected to progressive collapse. 


\section{REFERENCES}

[1] Gross, J.L., Mc Guire, W.: Progressive collapse resistant design, J. Struct. Eng., 109 (1983) 1, pp. 1-15, https://doi.org/10.1061/ (ASCE)0733-9445(1983)109:1(1)

[2] Casciati, F., Faravelli, L.: Progressive failure for seismic reliability analysis, Engineering Structures, 6 (1984) 2, pp. 97-103, https:// doi.org/10.1016/0141-0296(84)90002-6

[3] Sasani, M., Werner, A., Kazemi, A.: Bar fracture modeling in progressive collapse analysis of reinforced concrete structures, Eng. Struct., 33 (2011) 2, pp. 401-409, https://doi.org/10.1016/j. engstruct.2010.10.023

[4] Tsai, M., Lin, B.: Investigation of progressive collapse resistance and inelastic response for an earthquake-resistant RC building subjected to column failure, Engineering Structures, 30 (2008) 12, pp. 3619-3628.

[5] GSA, Progressive collapse analysis and design guidelines for new federal office buildings and major modernization projects. The US General Services Administration; 2003.

[6] Ahmadi, R, Rashidian O., Abbasnia, R, Mohajeri Nav, F., Usefi, N.: Experimental and Numerical Evaluation of Progressive Collapse Behavior in Scaled RC Beam-Column Subassemblage, Shock and Vibration, vol. 2016, Article ID 3748435, 17 pages, 2016, https:// doi.org/10.1155/2016/3748435

[7] Unified Facilities Criteria (UFC)-DoD. Design of buildings to resist progressive collapse. Department of Defense; 2005.

[8] Grierson, D.E., Xu, L., Liu, Y.: Progressive-failure analysis of buildings subjected to abnormal loading, Computer Aided Civil and Infrastructure Engineering, 20 (2005) 3, pp. 155-171, https://doi. org/10.1111/j.1467-8667.2005.00384.x

[9] Mohajeri Nav, F., Abbasnia, R., Rashidian, O., Usefi, N.: Theoretical Resistance of RC Frames under the Column Removal Scenario Considering High Strain Rates, J. Perform. Constr. Facil, 2016, https://doi.org/10.1061/(ASCE)CF.1943-5509.0000867

[10] Izzuddin, B.A., Vlassis, A.G., Elghazouli, A.Y., Nethercot, D.A.: Progressive collapse of multi-story buildings due to sudden column loss - Part I: Simplified assessment framework, Engineering Structures, 30 (2008), pp. 1308-1318, https://doi. org/10.1016/j.engstruct.2007.07.011

[11] Powell, G.: Progressive Collapse, Case studies Using Nonlinear Analysis. Structures Congress, pp. 1-14, 2005, https://doi. org/10.1061/40753(171)216

[12] Vlassis, A.G.: Progressive collapse assessment of tall buildings, Ph.D. thesis. Department of Civil and Environmental Engineering, Imperial College London, 2007.

[13] Marjanishvili, S., Agnew, E.: Comparison of various procedures for progressive collapse analysis, Journal of Performance of Constructed Facilities, ASCE, 20 (2006) 4, pp. 365-374, https:// doi.org/10.1061/(ASCE)0887-3828(2006)20:4(365)

[14] Alashker, Y., El-Tawil, S.: Design-oriented model for collapse resistance of composite floors subjected to column loss, J. Constr. Steel Res., 67 (2011) 1, pp. 84-92, https://doi.org/10.1016/j. jcsr.2010.07.008

[15] Ellingwood, B., Dusenberry, D.O.: Building design for abnormal loads and progressive collapse, Computer-Aided Civil and Infrastructure Engineering, 20 (2005) 3, pp. 194-205, https://doi. org/10.1111/j.1467-8667.2005.00387.x

[16] Luccioni, B.M., Ambrosini, R.D., Danesi, R.F.: Analysis of building collapse under blast loads, Eng. Struct., 26 (2004) 1, pp. 63-71, https://doi.org/10.1016/j.engstruct.2003.08.011
[17] Talaat, M.M., Mosalam, K.M.: Computational modeling of progressive collapse in reinforced concrete frame structures, Technical Rep. No. PEER 2007/10, Pacific Earthquake Engineering Research Center, Berkeley, CA., 2008.

[18] Faridmehr, I., Osman, M.H., Tahir, M.M., Nejad, A.F., Hodjati, R.: Evaluation of extreme load performance of pre-Northridge connections, GRADEVINAR 66 (2014) 10, pp. 889-898, https:// doi.org/10.14256/JCE.991.2013

[19] Kwasniewski, L.: Nonlinear dynamic simulations of progressive collapse for a multistory building, Engineering Structures, 32 (2010) 5, pp. 1223-1235, https://doi.org/10.1016/j. engstruct.2009.12.048

[20] Hao, H., Wu, C., Li, Z., Abdullah, A.K.: Numerical analysis of structural progressive collapse to blast loads, Trans Tianjin Univ, 12 (2006), pp. 31-34

[21] Shi, Y., Li, Z.X., Hao, H.: A new method for progressive collapse analysis of RC frames under blast loading". Engineering Structures, 32 (2010), pp. 1691-1703, https://doi.org/10.1016/j. engstruct.2010.02.017

[22] Yihai Lew, B., Sashi, K.: Modeling of Reinforced Concrete Assemblies under Column-Removal Scenario, Journal of Struct, Eng ${ }^{\odot}$ ASCE, ISSN (13), 2014.

[23] Yu, J., Tang, K.H.: Experimental and numerical investigation on progressive collapse resistance of reinforced concrete beam column sub-assemblages, Engineering Structures, 55 (2013), pp. 90-106, https://doi.org/10.1016/j.engstruct.2011.08.040

[24] Jun, Y., Kang, H.: Structural Behavior of RC Beam-Column Sub assemblages under a Middle Column Removal Scenario, J. Struct. Eng.,139 (2013), pp. 233-250, https://doi.org/10.1061/(ASCE) ST.1943-541X.0000658

[25] Choi, H., Kim, J.: Progressive collapse-resisting capacity of RC beam-column sub-assemblage, Magazine of Concrete Research, 63 (2011) 4, pp. 297-310, https://doi.org/10.1680/macr.9.00170

[26] Youpo, S., Ying, T., Xiaosheng, S.: Progressive Collapse Resistance of Axially-Restrained Frame Beams, ACI Structural Journal, 106 (2009) 5, pp. 600-607.

[27] Qian, K., Li, B., Ma, J.: Load-Carrying Mechanism to Resist Progressive Collapse of RC Buildings, J. Struct. Eng., 2014, https:// doi.org/10.1061/(ASCE)ST.1943-541X.0001046

[28] ABAQUS Version 6.13 Documentation, (2013).

[29] Lubliner, J., Olive,r J., Oller, S., Onate, E.: Aplastic-damage model for concrete. International journal of Solids and Structure, 25 (1989) 3, pp. 299-326, https://doi.org/10.1016/0020-7683(89)90050-4

[30] Jeeho, L., Gregory, L.: Plastic damage model for cyclic loading of concrete structures, J. Eng. Mech., 124 (1998), pp. 892-900, https://doi.org/10.1061/(ASCE)0733-9399(1998)124:8(892)

[31] Federal Highway Administration, Evaluation of LS-DYNA concrete material model 159., Publication No. FHWA-HRT-05-063, McLean, VA, (2007).

[32] Ashraf, M., Mohie, S., Janet, M.: Prediction of the behavior of reinforced concrete deep beams with web openings using the finite element method", Alexandria Engineering Journal, pp. 11101168, 2014.

[33] Aikaterini, S., Genikomsou Maria, A.: Finite element analysis of punching shear of concrete slabs using damaged plasticity model in ABAQUS, Engineering Structures, 98 (2015), pp. 38-48, https:// doi.org/10.1016/j.engstruct.2015.04.016 